\title{
Let the Land Heal You
}

\author{
Charlene Menacho* \\ University of Victoria \\ Charlene_03_@hotmail.com
}

\begin{abstract}
Colonization has affected Indigenous communities and created a major shift in Indigenous ways of being, knowing, and doing. This letter explores how colonization has caused trauma for Indigenous communities, specifically Dene men in the Northwest Territories. As a Dene woman and current student in a social work program, I work to uphold my responsibility to learn and be a resource to my people. In this letter, I will discuss the impacts of colonization on Dene men as a source of trauma, and the importance of returning to the land to heal oneself through Dene practices. I begin by discussing Dene people's relationship to the land as conveyed through our Creation Story. Next, I provide an overview of Dene experiences of colonization and systemic oppression. I then reflect on healing our historical trauma by returning to the land and allowing the land to heal us through ceremony.
\end{abstract}

Keywords: historical trauma; land-based healing; ceremony; colonization; Dene

$\mathrm{D}$ ear brothers, relatives, and those I have yet to meet, You are the reason I write this letter. As I write, I go between my mother's kitchen, in my home community of Tulita, and the University of Victoria, where I am attending school. When I am home, I am surrounded by family and friends. The sun rises and sets over the trees, rivers, lakes, and mountains, our four- and two-legged relatives, and the sacred sites that our ancestors left for us. I am lucky to call Tulita home. For those of you who are not familiar with my home community, Tulita is located in Denendeh, a name meaning "Land of the People" in the Dene language. Denendeh is known in English as the Northwest Territories. Tulita means "where the two waters meet" in the Dene language because it is located where the Mackenzie River and Great Bear River come together. It is a small remote community accessible by air and water in the summer and by the winter road in the winter. Its current population of 500 people includes Dene, Métis, and a few settlers. Tulita is my home, a place that I hold close to my heart. No matter where I go, my spirit is always drawn back.

As a future social worker, it is my responsibility to learn and educate myself about Dene ways of being and knowing, as well as our history, in order to be a resource for our community. In this letter, I will discuss the impacts of colonization on Dene men as a source of trauma, and the importance of returning to the land to heal oneself through Dene practices. Life in Tulita has not been easy. It has come with the challenges that many Indigenous communities face as a result of colonization and continued oppression, including a lack of resources to address social issues and health disparities. People fall victim to this vicious cycle of addiction, abuse, poverty, and trauma. Unfortunately, our community does not have adequate resources to address all of these issues, nor is there a safe outlet for community members to express what they are feeling or experiencing.

${ }^{*}$ To Kari, Gillian, and reviewers, mahsi cho for your time, support, and expertise. This piece would not be possible without you all. Mahsi cho to my mom, grandma, Conrad, Chloe, and relatives for their unconditional love, support, knowledge, and belief in me when I struggled to believe in myself. To my professor and mentor Billie Allan, mahsi cho for your encouragement to write this piece and teaching me how to be. Mahsi cho to all of Creation for guidance, love, and healing ways. 
More than anyone, this letter is meant specifically for my brothers Darryl, Matt, and Trev, who I will address directly here: Brothers, I am going to share some information with you. It will be difficult to read, but I want you to know that I am walking alongside you every part of the journey. You are the reason I wrote this letter. You are the reason I know kindness, love, and strength exist despite all the terrible things that have happened in our lives. I see how each of you embodies these qualities. Your laughter, hope, and resistance are woven into pain and anger. Please know that the pain and anger are not yours to carry. Our ancestors are here to guide us and help us, especially grandpa. He walks with us always and is a prayer away. Remember the teachings that grandpa left us along with his hugs, smile, and jokes. He loved us, our culture, and the land. Grandpa would want us to live our best lives and do the best we can. I love you and want nothing more than for you to see the gifts you carry and to know that I will always be here for you.

Though I write to you, I am a Dene woman and can only speak to my own experiences within the context of Tulita. I cannot fully understand what it means to be a Dene man who has experienced traumas stemming from colonization. As a sister, friend, relative, and future social worker, I seek to understand the impacts of colonization not just from my perspective, but from yours as well, so that I can be a resource when you need me. My intention for this letter is that you and other Indigenous men will understand that you are not alone in this struggle against colonization and systemic oppression.

It is important to understand that systemic oppression was created by colonization (Battiste, Bell, \& Findlay, 2002). Colonization means to dispossess and dominate a group of people in order to take land, resources, and people. Colonization is heartless and endless. Over the last 500 years, our people have experienced hardships including forced removal and relocation and continuing pressure to assimilate at the hands of the white settler-colonizers. Daes, at the 1999 UNESCO Conference on Education, noted, "Displacing systemic discrimination against Indigenous peoples created and legitimized by the cognitive frameworks of imperialism and colonialism remains the single most crucial cultural challenge facing humanity." Indigenous peoples' spirits, hearts, minds, and bodies suffered a devastating shock that gradually increased over time with the influx of European-Settlers and their trickster ways. EuropeanSettlers brought a different way of being in the world that was based on greed, power, and selfishness, in comparison to Dene law that was based on sharing, love, respect, and humility. Our ancestors want us to work together to fight colonialization by not allowing the tools of the oppressors to dismantle our lives. Our grandma says of my brothers,

I love them so much. I don't know what the alcohol will do to them and want them to find the right place for their future. Long time ago, people said we are going to run out of food from the land. Go on the land, start thinking about what was wrong and they will find themselves. In the future, whatever we did before it is going to come back to us-net axe... have it ready. Go on the right path, I always pray for the kids... to help the young people. Everything is on the land, food, medicine, sleigh, axe... if something happens, you are going to go to it (the land). (personal communication, December 1, 2019)

Returning to the land is one way to care for ourselves as we fight our way through colonialism and, as my grandma stated, there will be a time when we will need the land and animals to live and survive. I used to believe that my experiences were isolated and that no one else felt the pain I did, but eventually I realized that we share the same pain in different ways. I hope by sharing what I have learned and experienced with you all, that it will provide some clarity in your lives surrounding some of the pain you carry and that you will know that you are never alone. I want to provide further context surrounding some of the issues Dene men face with a clear understanding of the problems today. Although a portion of this letter focuses on the evil spirit called colonization, I do not want you to believe that is all we are; as Indigenous Peoples we are not the pain we carry. We are hope, love, resistance, strength, and joy neatly sewn together, like the floral designs on our moccasins. Like the moccasins, our spirits were made 
with love and beautifully sewn with purpose: each bead tacked down signifies our experiences, and the thread is the journey we are all on - let us not lose sight of our grandmothers' love as we walk this journey together in our smoked moose hide moccasins, decorated with colourful beads and beaver fur, as we allow the land to heal us.

\section{Understanding Ourselves as Dene}

Our lives were created with a purpose. Through the telling of the Dene Creation Story, our Elders remind us of our original instructions to live on and with the land respectfully. In the story, Mother Earth and animals were created first, followed by humans soon after. Dene people were one distinct group until a volcano divided them. When it erupted, "the people fled in terror in all directions, unable to understand one another because their languages had changed" (Abel \& Ebrary, 1993, p. 39). This volcano eruption caused the Dene people to separate and form distinct Nations such as the Tlicho (Dogrib), Dinjii Zhuh (Gwichin), K'ashot'ine (Hareskin), Denesoline (Chipewayn), Shúhtao'ịine (Mountain), K'alot'ine (Willowlake), Sahtúot'ine (Great Bear Lake), and Dehcho (South Slavey). Although I have only named the Dene tribes still within Denendeh, the Ndee (Apache) and Diné (Navajo) peoples also originated from our homelands, which is the reason our languages are similar.

As Dene people, we have always relied on Mother Earth and animals for survival. Therefore, we must maintain a respectful and humble relationship with all (The Department of Education, Culture and Employment, 2004). Our Dene ancestors traveled with the seasons and animals for food, shelter, and survival, while always returning to their fishing, hunting, and trapping areas. Although our ancestors faced starvation and conflicts with other tribes, they had everything they needed to live and survive. Their way of life was based on balance and harmony with all of Creation. Our ancestors were independent and relied on the land for tools and livelihood without domination over another person. They were respectful and treated each other equally (Helm, Carterette, \& Lurie, 2001).

\section{Understanding Dene Experiences of Colonization}

Colonization disregards the lives of Indigenous Peoples and works to disconnect us from the land by dismantling governing systems, teachings, and practices derived from the land so that the colonizers can establish their ways of life (Baskin, 2016). The beginning of change - the beginning of colonization - for the Dene people came when Europeans travelled to Denendeh. Alexander Mackenzie, a fur trader, was the first person to arrive in 1789. He came with a worldview, values, beliefs, and principles that were different from those of the Dene people. Once the fur traders established themselves among the Dene, they relied heavily on the Dene to survive and navigate the land. Without our ancestors, the fur traders would have not survived. The fur traders introduced the Dene to guns, tools, and European foods as trading commodities. This trade between the Dene and Europeans shifted reliance on the land to reliance on the fur traders for their tools and foods. Further, these fur traders paved the way for the missionaries to enter the Dene communities in the 1800s. They sought to replace Dene spirituality with the Catholic religion (Helm et al., 2001).

Change continued to happen rapidly for the Dene. Canada was founded in 1867 and its racist and cultural genocide policies advanced what hooks (2004) describes as an "imperialist white-supremacist capitalist patriarchy" (p. 17). In 1870, Canada acquired the Northwest Territories. In 1876, it passed the Indian Act - a piece of legislation designed to "kill the Indian" through assimilatory policies designed to erase Indigenous ways of being (Menzies, 2010). Amendments to the Indian Act established residential schools that divided and dismantled Indigenous knowledge systems and relationships with each other, the land, and spirituality. Many children were forced into the residential school system by the government, and parents were often fined or jailed if they did not obey the colonial law. Reeves and Stewart (2014) 
reveal that, in the span of 165 years, over 100,000 Indigenous children were forcibly removed from their families and put into the residential school system. This ultimately resulted in alcoholism, child abuse, suicide, and domestic violence in Indigenous communities (Menzies, 2010). The residential school system caused devastating harm to the minds, hearts, spirits, and bodies of the children and inflicted trauma that continued over generations.

In 1921, the Dene tribes signed Treaty 11 . Many Dene people were reluctant to sign as they were suspicious of the Europeans' agenda. The Dene sensed there was more to the treaty than what they were told. They suspected the treaty was a way to steal land or people. They knew there was no reason the Europeans were going to give money away. Priests and nuns worked on behalf of the Crown to deceive the Dene into surrendering land and way of life, and it became clear that they would not live together based on sharing and respect, as the Dene people had originally thought (Fumoleau, 1984). The Europeancolonizers negatively impacted our way of life and destroyed the land, animals, plants, language, and ceremony, as well as our minds, hearts, spirits, and bodies, all in the name of greed and power. The Dene did as they always had and cared for and treated others with respect, especially newcomers. Fumoleau (1984) notes that our ancestors did not steal anything that was not theirs, and the "white man taught dishonesty by example" (p. 380).

Colonization imposed a European governing system and worldview that was based on greed, individualism, and patriarchy. The European governing system used violence and "psychological terrorism" on anyone who was not a white male (hooks, 2004, p. 18). Patriarchy introduced a male-focused governing system that excluded women, divided kinship relations, changed our healing practices, taught men to dishonour themselves and community members, and made it so that women were no longer viewed as sacred, but as people to be disposed of and treated with no respect. If we forget who we are as Indigenous Peoples, we lose the value in our identity. If we look for acceptance within systems of patriarchy, colonialism, and white supremacy we will ultimately live a life that does not belong to us. Reeves and Stewart (2014) characterize colonization as the root cause of the issues that many Indigenous Peoples face today, and describe it as a spiritual wound that ultimately created chaos and, at times, a sense of helplessness amongst our ancestors due to the changing lifestyle.

\section{Historical Trauma, Continued Oppression, and Lateral Violence}

Colonization is ongoing and not a thing of the past. Our livelihoods and our relationships with self, community, Mother Earth, and spirit are negatively affected by the legacies of colonization. Some Dene men struggle to comprehend or recognize the implications of colonization, which has dominated and dismantled their relationships with self, others, land, and spirituality. If we do not deal with our pain, it will continue to control us in a harmful way. Brothers, I want you to remember the pain you carry is not yours to carry as it was given to our ancestors and passed down because of the sickness that the newcomers inflicted on our people. Colonization was meant to erase our ancestors, but our ancestors did not give up. They did their best to ensure we would have everything we needed. We come from strong ancestors who fought for us to be here and to live a good life.

Understanding the nature of colonization is the first step in breaking the cycle of intergenerational trauma that does not belong to us. This intergenerational trauma is also called historical trauma. Historical trauma is a stressful event that happens to a group of people in the past and continues into the next generation, and the residential school system is one example of historical trauma. Trauma derives from an overwhelming and stressful incident causing an emotional reaction, often enacted through harmful behaviours such as physical, emotional, and sexual abuse, which are passed from one generation to another and impact Indigenous mental health (Linklater, 2014). Linklater asserts that "addictions, violence, suicide, ... schizophrenia, depression, bipolar, post-traumatic stress" are symptoms of the trauma inflicted on Indigenous peoples (p. 21). Menzies (2010) describes some of the signs of trauma within 
individuals, families, and communities as low self-esteem, substance misuse, involvement with the criminal justice system, physical, sexual, emotional and verbal abuse, alcohol and drug misuse that crosses generations, lack of cultural support and opportunities, social policies that perpetuate colonialization, and lack of support for Indigenous needs. It is important to note that behaviours such as physical, sexual, emotional, and spiritual abuse are transmitted from one generation to another. This is learned behavior that stems from interaction with institutional figures. Colonization takes many forms that are often not readily visible. For this reason, one may not understand the struggles of today as stemming from the past. However, Indigenous men who have experienced sexual trauma feel vulnerable and "often experience fear, anger, shame, and guilt in the aftermath of their traumatic experiences, and they are more likely to engage in self-destructive and suicidal behaviour" (Reeves \& Stewart, 2014, p. 59), which is the reason many of them are unable to come forward about sexual abuse; it is linked with victim blaming and shame, and often there is no safe space or person to talk to about it. Baskin (2016) explains that those who have experienced some form of pain tend to hurt others without the ability to see the pain they have caused others due to their experience of abuse. During these abusive experiences, they learn to shut down their feelings, and many Indigenous men often find themselves in abusive or destructive relationships because of unhealed trauma or lack of acknowledgment of trauma. Indigenous men are more likely to be involved in a vicious cycle of drug and alcohol addiction as a way to cope with historical trauma, and many often find themselves in the criminal justice system without any support or culturally relevant programs. Clark (2016) asserts that criminalization is a colonial strategy that criminalizes and imprisons Indigenous youth and men without tangible plans to address the core issue, which is state violence and policies.

Our experiences of trauma are intertwined with experiences of oppression. Many of us have witnessed and experienced different forms of oppression in our communities. We have even perpetuated violence against ourselves. Lateral violence is the violence we learned from settler-colonizers and enact against each other through the use of hurtful words and actions, and it is prevalent in our communities. One of my Indigenous Studies professors at Camosun College explained lateral violence as crabs in a bucket. Each crab tries to get out of the bucket by pulling the other crabs down. We are like the crabs when we project our pain by bringing other people down through gossip, hostility, and hurtful actions to make ourselves feel better. It is time that we stop lateral violence. No one chose this life and each of us is doing what we need to survive. Lateral violence is not the way of our ancestors. It goes against our values of love, sharing, humility, and respect, and we must continually learn how to take care of ourselves and our relations while unlearning these harmful behaviours.

\section{A Personal Journey of Healing}

I know that some of this information is hard to grasp and that you may be feeling anger or sadness, and that is okay. One of the Elders I had the pleasure of knowing and being guided by is Vic Underwood, who taught me that "if you can cry, you can heal" (personal communication, 2017). Tears are one way that our bodies heal themselves. Expressing your tears, anger, and sadness is a way for you to care for yourself. I know that you were taught that showing your emotions is weak, but it is not. It is an act of self-love and how we honour our spirit. It can be easier to supress or avoid the pain than to deal with it. Sometimes we may not understand why we feel certain things. Taking the time to put our needs first will allow us to understand where the pain is coming from and to care for it appropriately. I can assure you that if we give ourselves the love and attention we deserve by being honest with ourselves and accountable, the outcome of no longer be tied down by our pain is worth it. I have been taught to honour our negative feelings as well as the good. To honour negative feelings means to acknowledge their purpose, be gentle and kind with yourself, and let go. We cannot undo the past, but we do have the opportunity to create a new beginning, starting with ourselves and honouring our spirit.

Healing is a lifelong journey that is not linear, but rather cyclical. I understand how complicated 
and messy it can be, especially during times when I was confused and lost about what I was feeling. I understand that the absence of my dad left me with insecurity issues today; however, there are some things I recently discovered that link my problems of today to my past experiences. I did not understand where the anger, lack of boundaries, confusion, depression, and anxiety stemmed from-I was not able to link the past of my relatives to the present day. As Dene people, all the hurt and pain we carry is not ours to carry - it is learned behaviour taught by the European-settlers. I do not blame those who hurt us because I understand that they did what they were taught; however, this does not mitigate the pain they caused. I know that hurt people hurt others. I found researching this topic I talk about in this letter to be therapeutic. There were parts of me that I struggled to understand, but I was able to find healing in the words of other authors. It is amazing and inspiring to read and feel the knowledge shared amongst so many Indigenous peoples. I feel truly honoured to walk this path knowing who paved the way. Although this topic is the starting point of broadening my understanding, I am grateful for what I have gathered and continue learning.

\section{Let the Land Heal You}

When I think about healing, my first thought is the land. Grandparents play an important role in our lives as Indigenous Peoples as they instill a love for all of Creation, including the land. Grandma often reminds me that we need to return to the land and our Dene ways because that is our where our main education lies, and I agree. The land is healing and has helped me during a difficult time in my life. I was going through a wave of depression and was not sure how to deal with it because I was not at home. In September of 2018, I attended a cultural camp that was part of my Indigenous Studies program at Camosun College in Victoria, BC. My class and I went walking in the woods with each of us going our separate ways. I walked to an open area where leaves were falling. They stopped as soon as I sat down on a log. I planted my hands down onto the $\log$ and started praying. As I prayed, I started crying and felt a vibration between my hands. The log took my pain away and I left feeling light, happy, and content. It was a huge weight lifted from my spirit. It was a powerful and spiritual experience I will never forget. At that moment, I remembered that-regardless of where I am - the land will always be there to help when needed.

Radu, House, and Pashagumskum (2014) emphasize the importance of the land and asking Mother Earth for help without being afraid to do so. I have stated previously that the land is the foundation of who we are as Dene people. Without it, who are we? Richard Nerysoo (as cited in Berger, 1977) captures the very essence of being Dene as an extraordinary gift. To live and understand this world in this way means

living with the land, with the animals, with the birds and fish, as though they were your sisters and brothers. It means saying the land is an old friend and an old friend your father knew, your grandfather knew, indeed your people have always known [...] we see our land as much, much more than the white man sees it. To the Indian people our land really is our life. Without our land we cannot-we could no longer exist as people. If our land is destroyed, we too are destroyed. (p. 94)

The words of Nerysoo remind us of the profound relationship we have with all of Creation, dependent on respect and love. With the colonial shift in our Indigenous ways, people tend to forget that or were not taught about upholding our kinship relations. Creator, Ancestors, and spirits of the land are waiting and wanting to help; all we need to do is ask for help and guidance. Simpson (2014) states that "if we do not create a generation of people attached to the land and committed to living out our culturally inherent ways of coming to know, we risk losing what it means to be [Indigenous] within our own thought systems" (p. $13)$. 
Corntassel and Bryce (2012) examine the importance of resurgence and reclamation of Indigenous practices by living and breathing it daily. One example that I can imagine is returning to the cultural teachings of the past, such as rites of passage for Dene men. Rites of passage were a sacred time as boys transition to adults during the stage of puberty. The rites of passage involved separation from girls, and being mentored and taught by other men to participate in ceremony such as dreams, or vision quests, which provided them with their medicine power, or purpose in life (Department of Education, Culture and Employment, 2004). Another important aspect of the rites of passage was the first hunt, which included sharing the meat with the community, constructing and repairing tools that were made of bone, stone, and wood, and learning how to travel on the land by connecting and reading the land and weather for direction and time. This taught the boys how to live a good life by helping others, acquiring spiritual strength, and respecting the land and others (Department of Education, Culture and Employment, 2004). The reclamation of these Dene practices is important because the rites of passage instill Dene values, beliefs, and ceremony at a young age, and create a space of belonging, connection, strength, and identity that helps the younger generation in life.

Although resuming the rites of passage is one way to set the foundation of strength, love, and belonging, this practice is not something that is currently in place for you and other Dene men. I hope this letter will start a conversation about what is needed in our community. I hope that what I have shared has given you some hope for your future, and that you now know that you are not alone in what you are feeling and what you have experienced, and that it is normal and okay to feel what you do. There are other men who are struggling to get the help they need, but do not know where to turn. Trauma can cause fear, anxiety, and depression. In turn, it makes people turn to unhealthy coping mechanisms such as drinking and drugs that can make people do things they are not proud of. To move forward in a good way, accountability is important. I had to be accountable for my actions and take full responsibility to move forward. We all have a responsibility and purpose for walking on this earth, and I know that you are more than your mistakes, more than your addiction, more than your pain; you deserve a good life filled with love, laughter, and connection.

\section{Returning to Ceremony}

Take care of the land so the land can take care of us. Simpson (2014) beautifully states the importance of connecting with Indigenous knowledge through dreams, visions, and ceremony as a starting point because that is where the ancestors and spiritual beings exist and a place where the spirits of plants, animals, and humans interact. Like you, I am a learner and always will be. I do not carry all the answers, but I have learned to ask through ceremony, such as the sweat lodge, smudging, feeding of the fire, and praying. I ask for guidance from our ancestors and Creator when I need help or clarity. I give thanks every day to them as well. I know that some people will say "it is not our way," but I can assure that you that it was at one time, before the fur traders and missionaries. We had our own spirituality that we all relied on, which centred our spirit within all of Creation.

I understand that smudging and sweat lodge might not be accessible and that you may not understand the protocols to be in ceremony. There are other ways that you can care for yourself: pray; talk to someone you trust; write your feelings down and burn the paper afterward; go to the river or lake and cleanse yourself; walk along with the trees and let the branches brush the sadness away; sit on a $\log$ and give it your pain-Creator gave us what we need to help ourselves; it is about asking for it and being open to it. The land is there to help us, just like our ancestors and Creator. I have always connected with the land and with the education I have received through Elders, knowledge carriers, and my ancestors, and I hope to create land-based programs that focus on healing our mind, heart, body, and spirit from trauma, depression, and oppression. I hope you know that I carry your heart in mine, and I will meet you wherever you are and remind you of the beautiful spirit you are. You on this earth for a reason. 
The Arbutus Review • $2020 \bullet$ Vol. 11, No. 1 Special Issue on Indigenous Wellness •

\section{Conclusion}

I end this letter by acknowledging the healing that transpired through researching this topic. To love ourselves goes against the oppressor's wishes. We are not meant to suffer, and so it is important to honour our spirit by working every day towards balance in our lives. As I peel away the layers of trauma from colonization - through prayer, ceremony, stories, and connection with the land - I feel sad and angry about the loss we have endured as Indigenous peoples. At the same time, I am reminded of the beauty of our people and our Indigenous ways of life. One by one, we are reclaiming our languages, ceremonies, kinship relations, and relationship with all of Creation. The land is healing, if we believe and ask for help. I struggle with being far from home, not being able to help you, my relatives. I am constantly imagining different ways I can be a resource. In writing this letter, I was reminded of the strength, respect, and humility of my ancestors. Often, living in the city is isolating and lonely; I try to remember why I am here at school and pursuing my social work degree. Although I am not able to return to home permanently just yet, I can do the work by learning about different ways that colonization impacted our people and uncover Dene ceremonies to heal and nurture the mind, heart, spirit, and body.

With all of my love, I carry your heart in mine,

Charlene Menacho

Summer 2020 
The Arbutus Review • $2020 \bullet$ Vol. 11, No. 1 Special Issue on Indigenous Wellness • https://doi.org/10.18357/tar111202019461

References

Abel, K. M., \& Ebrary, I. (1993). Drum songs: Glimpses of dene history. Montreal, QC: McGill-Queen's University Press.

Baskin, C. (2016). Strong helpers' teachings: The value of Indigenous knowledges in the helping professions. Toronto, ON: Canadian Scholars' Press Inc.

Battiste, M., Bell, L., \& Findlay, L. M. (2002). Decolonizing education in Canadian universities: An interdisciplinary, international, indigenous research project. Canadian Journal of Native Education, 26(2), 82 .

Berger, T. R. (1977). Northern frontier, northern homeland: The report of the Mackenzie Valley Pipeline Inquiry. Ottawa, ON: Supply and Services Canada.

Corntassel, J. \& Bryce, C. (2012). Practicing sustainable self-determination: Indigenous approaches to cultural restoration and revitalization. The Brown Journal of World Affairs, 18(2), 151-162.

Clark, N. (2016). Shock and awe: Trauma as the new colonial frontier. Humanities, 5(14), 1-16. https://doi.org/10.3390/h5010014

Daes, E. (1999). Cultural challenges in the decade of Indigenous peoples. Unpublished paper presented at the UNESCO Conference on Education. Paris, France, 1999 July.

Department of Education, Culture and Employment. (2004). Curriculum Document Grade 9: Dene Kede. https://www.ece.gov.nt.ca/sites/ece/files/resources/dene_kede_grade-9_curriculum.pdf

Flowers, R. (2015). Refusal to forgive: Indigenous women's love and rage. Decolonization: Indigeneity, Education \& Society, 4(2), 32-49. https://jps.library.utoronto.ca/index.php/des/article/download/22829/19320/

Fumoleau, R. (1984). Denendeh: A dene celebration. Yellowknife, NWT: Dene Nation.

Helm, J., Carterette, T. S., \& Lurie, N. O. (2001). The people of Denendeh: Ethnohistory of the Indians of Canada's Northwest Territories. Iowa City, IA: University of Iowa City.

hooks, b. (2004). The will to change: Men, masculinity and love. New York, NY: Washington Square Press.

Linklater, R. (2014). Decolonizing trauma work: Indigenous stories and strategies. Winnipeg, MB: Fernwood Publishing.

Menzies, P. (2010). Intergenerational trauma from a mental health perspective. Native Social Work Journal, 7, 63-85. https://www.collectionscanada.gc.ca/obj/thesescanada/vol2/OSUL/TC-OSUL384.PDF

Radu, I., House, L.M., \& Pashagumskum, E. (2014). Land, life and knowledge in Chisasibi: Intergenerational healing in the bush. Decolonization: Indigeneity, Education \& Society, 3(3), 86-105. https://jps.library.utoronto.ca/index.php/des/article/download/21219/18048/

Reeves, A., \& Stewart, S. L. (2014). Exploring the integration of Indigenous healing and western psychotherapy for sexual trauma survivors who use mental health services at Anishnawbe Health Toronto. Canadian Journal of Counselling and Psychotherapy, 49(1). https://cjc-rcc.ucalgary.ca/article/view/61008

Simpson, L (2014). Land as pedagogy: Nishnaabeg intelligence and rebellious transformation. Decolonization: Indigeneity, Education \& Society 3(3), 1-25. https://jps.library.utoronto.ca/index. $\mathrm{php} / \mathrm{des} /$ article/view/22170 